\title{
Education System and Its Importance in the Context of Bangladesh Education System
}

\author{
Dr. Masud Al Noor \\ Dept.of Apparel Manufacturing Management \& Technology \\ Shanto-Mariam University of Creative Technology
}

\begin{abstract}
Education is the back bone of the nation. Without proper education it cannot be possible to make a wise nation. Bangladesh education system is not competitive in terms of compare with international level. Lack of unified curriculum and skilled teacher is the main factor to develop education sector and political illness is another factor to improve those system. It is time to identify the problems and find out the remedy. With a strong education system a highly qualified generation may emerge to lead Bangladesh in realizing the dreams and goals of the nation. The paper presents a significant analysis of education system of Bangladesh.
\end{abstract}

Key Words: Education System, University Grants Commission, Higher Education, Quality Assurance

\section{INTRODUCTION}

The education system in Bangladesh encompasses both formal and non-formal education. Both types are available in a religious variant. Non-formal education encompasses organized, structured learning that takes place outside of the school environment. Examples of this include programmes aimed at tackling illiteracy, work related or talent development programmes, such as company training and lifelong learning programmes, but also training programmes for those who have left school without a qualification. Non-formal education is provided at a variety of levels.

The Ministry of Education (MoE) and the Ministry of Primary and Mass Education (MoPME) share responsibility for the entire education system, with the MoE responsible for all education after primary education. This includes religious education (taught at Madrasahs) and technical and secondary vocational education. The MoE prepares legislation and regulations, drafts policies and carries out supervision of educational institutions. The MoPME is responsible for primary education and non-formal education. University Grants Commission plays an advisory, supervisory and regulatory role in respect of higher education in Bangladesh.

The Bangladesh Technical Education Board (BTEB) is responsible for the development of technical and professional education. BTEB also organizes examinations for various programmes and awards the certificates.

Established in 1992 to develop higher education at Degree colleges, the National University formed an umbrella organization for all colleges offering general education programmes at bachelor's and master's level. It is basically an affiliating institution which administrates examinations and awards diplomas on behalf of its affiliated institutions.

The country's official language is Bengali. The second (not official) language is English. Further Urdu \& hindi spoken by non-Bengali Muslims in Bangladesh. English is widely used in higher education. Medium of instruction is English at both public and private universities. School 
attendance is compulsory from grades I to $\mathrm{V}$, i.e. for the entire duration of primary education. There are plans to extend compulsory schooling to grade VIII, meaning that it would also include the junior years of secondary education.

\section{METHODOLOGY}

Both primary and secondary data source has been introduces to make the report. Interviews of students in different types of educational institutions and teachers have also been undertaken to complement literature review. Finally direct observation of performance of students from diverse backgrounds at the higher levels added significantly to the study.

\section{LITERATURE REVIEW}

There has been success in increasing enrollment from 58\% to 94.8\% by 2010 (BANBEIS 2010) which bodes well for attaining the target of $100 \%$ enrollment by 2015 set by the current government keeping in line with UN. On the other hand, however, dismal figures in retention mar this success and in conjunction with other major problems such as quality and standard threaten to deflect achievement of desired goals (UNICEF, 2008). While trying to bring under primary education the remaining 3.3 million out-of-school children the government should ensure that quality is not compromised.

Furthermore, it may be noted that there has been a total lack of uniformity in the curriculum followed by educational institutions in Bangladesh despite being mandated by the constitution of the country. Article 17 of the constitution states: The state shall adopt effective measures for the purpose of - a) establishing a uniform, mass-oriented and universal system of education and extending free and compulsory education to all the children to such stage as may be determined by law; b) relating education to the needs of society and producing properly trained and motivated citizens to serve those needs. c) Removing illiteracy within such time as may be determined by law.(The Constitution of the People's Republic of Bangladesh, 2000) Before proceeding further the goals of education in Bangladesh need to be reviewed. Each commission set out building up their policy based on some preset ideals or goals. The first commission was the Kudrat-i-Khuda Commission of 1972. This is of highest significance as the education policy of this commission has been the basis for all future endeavors. The Kudrat-iKhuda commission spelled out its purpose concisely thus: "To develop and nurture the child's moral, mental and social personality; to bring up the child as a patriotic, responsible, inquiring and law-abiding citizen, and develop in him/her love for justice, dignity, labour, proper conduct and uprightness; to learn to read and write in the mother tongue and to be able to count and calculate; to be able to acquire the fundamental knowledge and skills needed for a future citizen; to prepare for the next stage of higher education." (Education Commission, 1974).

\section{THE EDUCATION SYSTEM}

The main education system is divided into three levels:

- Primary Level (Class 1-8)

- Secondary Level (Class 9-12)

- Tertiary Level

At all levels of schooling, students can choose to receive their education in English or Bangla. Private schools tend to make use of English-based study media while government-sponsored schools use Bangla. 


\section{Primary education}

The overall responsibility of management of primary education lies with the Ministry of Primary and Mass Education (MOPME), set up as a Ministry in 1992. While MOPME is involved in formulation of policies, the responsibility of implementation rests with the Directorate of Primary Education (DPE) headed by a Director General. The Directorate of Primary Education (DPE) and its subordinate offices in the district and upazila are solely responsible for management and supervision of primary education. Their responsibilities include recruitment, posting, and transfer of teachers and other staff; arranging in-service training of teachers; distribution of free textbooks; and supervision of schools. The responsibility of school construction, repair and supply of school furniture lies with the DPE executed through the Local Government Engineering Department (LGED). The National Curriculum and Textbook Board (NCTB) is responsible for the development of curriculum and production of textbooks. While the Ministry of Education (MOE) is responsible for formulation of policies, the Directorate of Secondary and Higher Education (DSHE) under the Ministry of Education is responsible for implementing the same at secondary and higher education levels. The NCTB is responsible for developing curriculum and publishing standard textbooks.

The Directorate of Primary Education (DPE) is responsible for conducting the two public examinations:

- Primary School Certificate (PSC) (5th grade)

- Junior School Certificate (JSC) (8th grade)

\section{Secondary education}

The secondary level of education is controlled by the eight General Education boards:

- Barisal Education Board for Barisal Division

- Chittagong Education Board for Chittagong Division

- Comilla Education Board for Comilla Division

- Dhaka Education Board for Dhaka Division and Mymensingh Division

- Dinajpur Education Board for Rangpur Division

- Jessore Education Board for Khulna Division

- Rajshahi Education Board for Rajshahi Division

- Sylhet Education Board for Sylhet Division

The boards' headquarters are located in Barishal, Comilla Chittagong, Dhaka, Dinajpur Jessore, Rajshahi and Sylhet.

Eight region-based Boards of Intermediate and Secondary Education (BISE) are responsible for conducting the two public examinations:

- Secondary School Certificate (SSC) (10th grade)

- Higher Secondary School Certificate (HSC) (12th grade)

At the school level, in the case of non-government secondary schools, School Management Committees (SMC), and at the intermediate college level, in the case of non-government colleges, Governing Bodies (GB), formed as per government directives, are responsible for mobilizing resources, approving budgets, controlling expenditures, and appointing and disciplining staff. While teachers of non-government secondary schools are recruited by concerned SMCs observing relevant government rules, teachers of government secondary schools are recruited centrally by the DSHE through a competitive examination. 
In government secondary schools, there is not an SMC. The headmaster is solely responsible for running the school and is supervised by the deputy director of the respective zone. Parent Teachers Associations (PTAs), however, exist to ensure a better teaching and learning environment.

\section{Tertiary education}

At the tertiary level, universities are regulated by the University Grants Commission.The colleges providing tertiary education is under the National University. Each of the medical colleges is affiliated with a public university. Universities in Bangladesh are autonomous bodies administered by statutory bodies such as Syndicate, Senate, Academic Council, etc. in accordance with provisions laid down in their respective acts.

\section{Madrasha Education}

The Madrasah Education System focuses on religious education, teaching all the basics of education in a religious environment. Religious studies are taught in Arabic and the students in some areas also serve the local area masjids. Students also have to complete all the courses from the General Education System. Many privately licensed Madrasas take in homeless children and provide them with food, shelter and education, e.g. Jamia Tawakkulia Renga Madrasah in Sylhet. In the Madrasah Education System there are two systems:

One, called the "Quomi" Madrasah system is privately owned and funded and is run according to the Deobandi system of Islamic education, which rejects the rational sciences.

The other, called the "Alia" madrasah system, is privately owned but subsidised by the government (the government spends $11.5 \%$ of its education budget on alia madrasahs, paying $80 \%$ of teacher and administrator salaries). ${ }^{[10]}$ Quomi madrasahs account for $1.9 \%$ of total primary enrollment and $2.2 \%$ of secondary enrollment; aliyah madrasahs account for $8.4 \%$ of primary and $19 \%$ of secondary enrollment. ${ }^{12]}$ The alia system is like the general education system, except that Arabic is taught in addition to general education. The Madrasah Education Board covers religious education in government-registered Madrasahs in the secondary level. After passing "Alim", a student can enroll for 3 additional years to obtain a "Fazil" level. Students can go for further general education and earn a university degree. After passing successfully, they can further enroll for another 2 years to obtain a "Kamil" level degree.

The following table -1 provides a statistical comparison of the "Quomi" and "Alia" madrasah systems.

\begin{tabular}{|l|l|}
\hline $\begin{array}{l}\text { Profile of Madrasahs Education in } \\
\text { Bangladesh }\end{array}$ & \\
\hline Number of private (Quomi) Madrasahs & 13,902 \\
\hline $\begin{array}{l}\text { Number of government-funded (Alia) } \\
\text { Madrasahs }\end{array}$ & 6906 \\
\hline Number of teachers in Quomi Madrasahs & 130,000 \\
\hline Number of teachers in Alia Madrasahs & 100,732 \\
\hline Number of students in Quomi Madrasahs & $1,462,500$ \\
\hline Number of students in Alia Madrasahs & $1,878,300$ \\
\hline Total number of Madrasahs (Quomi + Alia) & 13,406 \\
\hline Total number of teachers (Quomi + Alia) & 230,732 \\
\hline Total number of students (Quomi + Alia) & $3,340,800$ \\
\hline
\end{tabular}




\section{ALTERNATIVE EDUCATION SYSTEM}

Technical and Vocational Education

The Technical and Vocational Education System provides courses related to various applied and practical areas of science, technology and engineering, or focuses on a specific specialized area. Course duration ranges from one month to four years. The Technical Education Board controls technical and vocational training in the secondary level.

The Directorate of Technical Education (DTE) is responsible for the planning, development, and implementation of technical and vocational education in the country. Curriculum is implemented by BTEB. There are also a number of private universities in Bangladesh. In the Technical Education System, after obtaining a Diploma-in-Engineering degree (four-year curriculum) from the institutes listed below, students can further pursue their educational career by obtaining a bachelor's degree from Engineering \& Technology Universities. It normally it takes an additional two and a half to three years of coursework to obtain a bachelor's degree, although some students take more than three years to do so. They can then enroll in post-graduate studies. Students can also study CA (Chartered Accounting) after passing HSC or bachelor's degree and subject to fulfilling the entry criteria of the Institute of Chartered Accountants of Bangladesh (ICAB).

\section{English Language Schools}

A vast number of schools in Bangladesh are English version schools. English Medium schools are mainly private schools where all the courses are taught in English except one Bengali Language subject at ordinary level (O level). These schools in Bangladesh follow the General Certificate of Education (GCE) syllabus where students are prepared for taking their Ordinary Level (O level) and Advanced Level (A Level) examinations. The General Certificate of Education system is one of the most internationally recognized qualifications, based in the United Kingdom. The Ordinary and Advanced Level examinations are English equivalent to the Secondary School Certificate (SSC) and Higher Secondary School Certificate (HSC) examinations respectively. Most students sit for these exams from the registered schools in Bangladesh who follow the GCE syllabus. Those who do not attend a school that follows the GCE syllabus may also sit for their Ordinary and Advanced Level examinations from the British Council. These examinations are conducted under the supervision of the British Council in Bangladesh. The GCE examination conducted by the British Council takes place twice a year. Currently there are two boards operating from Bangladesh for Ordinary and Advanced Level Examinations, which are Edexcel and University of Cambridge International Examinations. Bangladesh has recently opened English Version education translating board textbooks in English. 
Figure 1: Education in Bangladesh

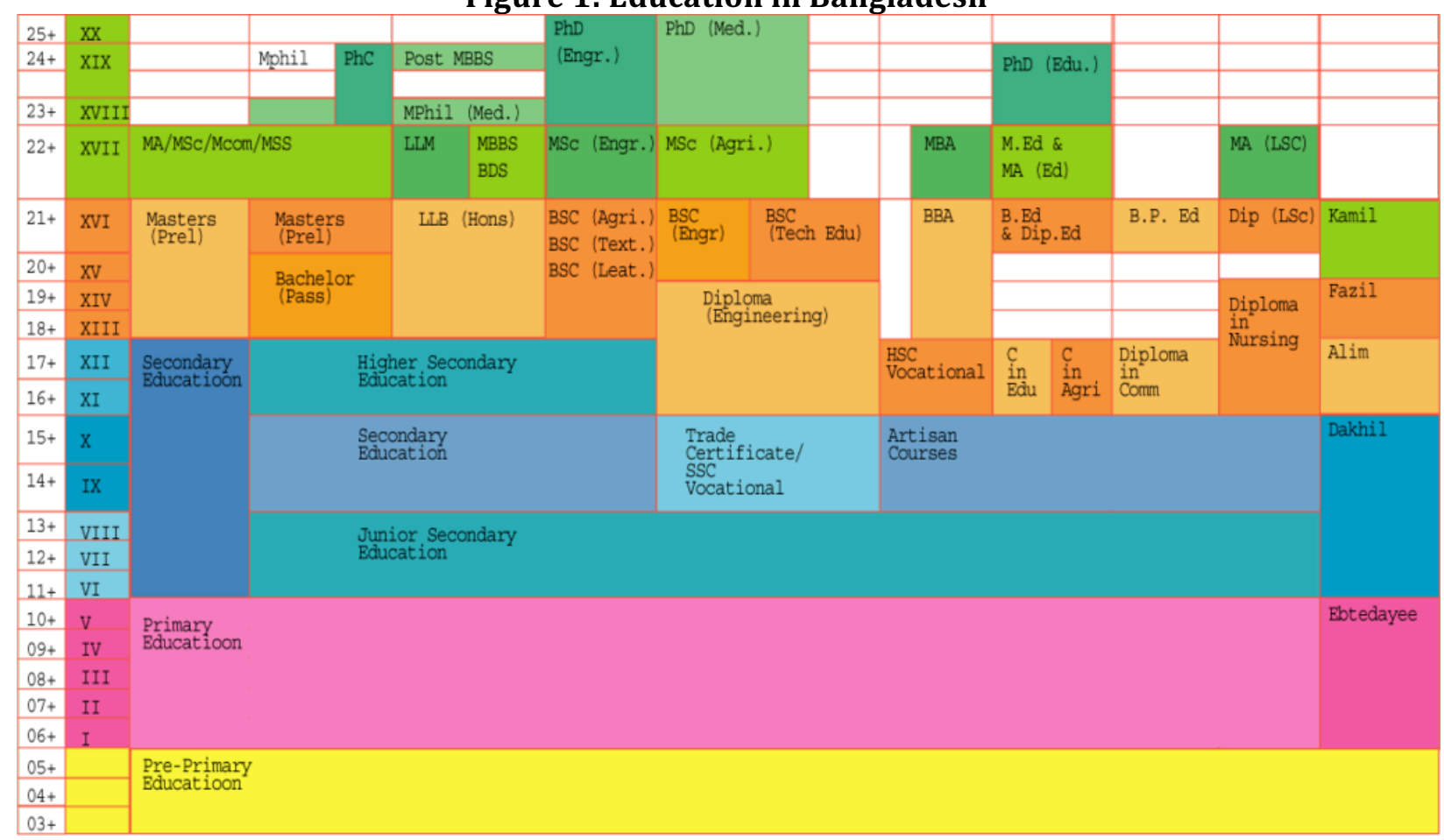

Figure: Bangladesh education system chart (adapted from: BANBAIS 2008)

\section{Curriculum}

This first major step was taken in 1972 when the constitution was introduced in independent Bangladesh. The constitution rightly recognizes and declares education under article 17 as a basic right of the people. The then government also understood the significance of education at the primary level and an ordinance was passed on October 1973 nationalizing a large number of primary schools thus opening the doors to education for the masses. In addition a law was passed to further strengthen the efforts in 1974 which basically thrust upon the government the responsibility to bring all primary education under a centralized administration.

\section{Qualification of Teachers}

Currently a deplorable situation exists. In a research carried out it was found that most teachers at the primary level were under qualified - mostly secondary school graduates sporting third divisions (Rabbi, 2008). Most teachers also lack any sort of training and are not mentally suitable as teachers and mentors of the minds of the future generations. In many cases, teachers are more interested in private tutoring rather than mentoring and teaching in regular classes and students greatly suffer from this both academically and financially. Apparently lax appointment requirements for primary teachers are partly to blame for this. Moreover, the government should bear blame since primary school teachers are given extremely poor salary and a status that is lowest among the government employees (Rabbi, 2008; UNICEF, 2008). Thus understandably high caliber applicants are dissuaded. The government needs to realize that this self-defeating policy is reflected in the quality and commitment of the teachers. It may be noted that where primary schools are expected to provide at least 900 contact hours per year, less than 10\% actually do so (DPE, 2008).

\section{Method of Teaching and Evaluation}

One of the most unfortunate things about education in Bangladesh is the style of teaching. Memorization is standard way of learning. Teachers expect students to memorize a huge amount of data and regurgitate them during exams. Courses are not designed to stimulate discussion and analytical thinking in classrooms. Furthermore, when the amount of 
memorization becomes overwhelming for the student the student naturally looks for short cuts. This calls for suggestions and also the leakage (sales) of actual question papers. This also calls for innovative methods of cheating - the same innovativeness of which the teacher and the education board could have made better use. Students cheat because it is the only alternative (to memorizing impossible amounts) left to them. The responsibility again falls on the teachers and those who set the syllabi. Thus the teacher in the present system teaches very little and the student learns very little other than cheating and regurgitation. Memorization encourages cheating and discourages thinking and so the existing system produces unthinking generations of cheating future leaders. How can one expect Bangladesh to progress? According the UNICEF, Bangladesh, the culture of memorization discourages students tremendously and is a major cause of poor achievement and low retention. They also cite this as a reason for high failure rates and repetition of classes which forces students to spend almost 9 years in primary school instead of 5 (UNICEF 2010). Overwhelming syllabi and a culture of memorization coupled with stressful hall exams which gives comparative evaluation create cheating, overcompetitive and selfish individuals who will only perform in return for benefits. Einstein thus laments, 'Our whole educational system suffers from this evil. An exaggerated competitive attitude is inculcated into the student, who is trained to worship acquisitive success as a preparation for his future career.' (Einstein, 1949)

\section{Gender Disparity}

In Bangladesh, gender discrimination in education occurs amongst the rural households but is non-existent amongst rich households. There is great difference in the success rates of boys, as compared to girls in Bangladesh. However, in recent years some progress has been made in trying to fix this problem.

\section{School Attendance}

The low performance in primary education is also matter of concern. School drop-out rates and grade repetition rates are high. Poor school attendance and low contact time in school are factors contributing to low level of learning achievement.

\section{Literacy Rate}

Bangladesh has one of the lowest literacy rates in Asia, estimated at $66.5 \%$ for males and $63.1 \%$ for females in 2014. Recently the literacy rate of Bangladesh has improved as it stands at $71 \%$ as of 2015 due to the modernization of schools and education funds.

\section{Assessment systems}

Secondary education For SSC and HSC, the following system has been in use since 2004 .

Table 2: indicates the calculation of grade point since 2004

\begin{tabular}{|l|l|l|l|}
\hline In numbers & Grade Point & Letter grade & Meaning \\
\hline $80-100$ & 5 & A+ & Excellent \\
\hline $70-79$ & 4 & A & Very good \\
\hline $60-69$ & 3.5 & A- & Good \\
\hline $50-59$ & 3 & B & More than satisfactory \\
\hline $40-49$ & 2 & C & More than satisfactory \\
\hline $33-39$ & 1 & D & Satisfactory \\
\hline $00-32$ & 32 & F & Unsatisfactory \\
\hline
\end{tabular}


Higher education In 2006 / 2007, the University Grants Commission (UGC) introduced the Uniform Grading Scheme for all universities in Bangladesh.

Ttable 3: UGC approved grade point since 2006

\begin{tabular}{|l|l|l|l|}
\hline $\begin{array}{l}\text { In } \\
\text { numbers }\end{array}$ & $\begin{array}{l}\text { Grade } \\
\text { Point }\end{array}$ & $\begin{array}{l}\text { Letter } \\
\text { grade }\end{array}$ & Description \\
\hline $\begin{array}{l}80 \% \text { and } \\
\text { higher }\end{array}$ & 4.0 & A+ & A plus \\
\hline $75 \%-80 \%$ & 3.75 & A & A regular \\
\hline $70 \%-75 \%$ & 3.5 & A- & A minus \\
\hline $65 \%-70 \%$ & 3.25 & B+ & B plus \\
\hline $60 \%-65 \%$ & 3.0 & B & B regular \\
\hline $55 \%-60 \%$ & 2.75 & B- & B minus \\
\hline $50 \%-55 \%$ & 2.5 & C+ & C plus \\
\hline $45 \%-50 \%$ & 2.25 & C & C regular \\
\hline $40 \%-45 \%$ & 2.0 & D & \\
\hline $40 \%$ & 0.0 & F & \\
\hline
\end{tabular}

$\mathrm{I}=$ Incomplete grade;

$\mathrm{W}=$ Withdrawn

\section{Qualification Frameworks}

Bangladesh has not (yet) established a national qualifications framework. There are plans, however, for a National Technical and Vocational Qualification Framework (NTVQF), which will primarily focus on secondary vocational education.

\section{Quality Assurance and Accreditation}

There is no national quality assurance system in Bangladesh. To provide assurances of the quality of higher education, one of the duties of the University Grants Commission (UGC) is to promote and coordinate university education and to monitor and maintain quality standards. However, the UGC is not an accreditation body. UGC is now ensuring quality in higher education mainly by enforcing minimum requirements in respect of opening and operation of higher education institutions and the programmes the institutions offer.

Under Section 38 of the new Private Education Act (2010), the Ministry of Education is currently considering establishing an Accreditation Council for Private Universities of Bangladesh (ACPUB), making membership compulsory for all private universities. No such accreditation body has yet been mooted for public sector universities. However, public universities have some sort of built-in mechanism to ensure quality of education.

Made up of four component parts, the University Grants Commission's Higher Education Quality Enhancement Project (HEQEP) is aimed at improving the quality of higher education. The first part encompasses funds made available to universities in conjunction with proposals to improve the quality of the education they provide: the Academic Innovation Fund (AIF). The second part encompasses the design of a Higher Education Management Information System (HEMIS): computer software programmes intended to provide management with administrative and academic data, for instance, the number of students admitted how they are performing, as well as information on study programmes and alumni. HEMIS will be implemented at the national and institutional levels. The third part encompasses the establishment of the Bangladesh Research and Education Network (BdREN), which will aim to facilitate professional liaison between researchers and academic staff at the national level. The 
final part encompasses the project management of HEQEP, the aim of which is to ensure smooth progress with the preparations for and implementation of the entire project.

The website of the University Grants Commission can be consulted to check whether a university has accredited status. For other institutions, refer to the link to the website of the Ministry of Education. See under List of higher education institutions.

Fig : National Education Budget 2015,general details, literacy rate ,enrollment (source :ministry of education )

\begin{tabular}{|l|l|}
\hline \multicolumn{2}{|c|}{ National education budget (2015) } \\
\hline Budget & $\begin{array}{l}\text { US } \$ 2.185 \text { billion } \\
\left(172.951 \text { billion Taka) }{ }^{[1]}\right.\end{array}$ \\
\hline \multicolumn{1}{|c|}{ General details } & \\
\hline Primary languages & Bengali, English \\
\hline System type & National \\
\hline Established & 4 November 1972 \\
Compulsory Education & \\
\hline \multicolumn{1}{|c|}{ Literacy (2015+) } & \\
\hline Total & $75.4 \%$ \\
\hline Male & $77.1 \%$ \\
\hline Female & $71.5 \%$ \\
\hline \multicolumn{1}{|c|}{ Enrollment } & \\
\hline Total & $23,907,151$ \\
\hline Primary & $16,230,000$ \\
\hline Secondary & $7,400,000$ \\
\hline Post secondary & 277,151 \\
\hline Attainment & 335,454 \\
\hline Secondary diploma & 86,948 \\
\hline Post-secondary diploma & \\
\hline
\end{tabular}

\section{CONCLUSION}

Without education it cannot be possible to develop peoples mind and thought. Various points has been mentioned in this article. Currently its syllabus and curriculum threaten for the students mind .entire country would suffer socially, economically, technologically and politically .education is the heart of the nation. Without heart no one can live, like wise without proper education the country is stepping backwards .education board, university grants commission \& government need to look after the curriculum seriously to improve the education system effectively.

\section{References}

Mohit Prodhan; 'the present situation of education system in Bangladesh and scope for improvement '; jess, vol.4 (June 2016). 
Primary education now up to class VIII". The Daily Star. 18 May 2016. Retrieved 12 September 2016.

"Primary education up to class VIII, secondary XII". The Daily Star. 25 August 2009. Retrieved 12 September 2016.

Millennium Development Goals: Bangladesh Progress Report 2015. General Economics Division (GED), Bangladesh Planning Commission. plancomm.gov.bd.

"The Constitution of the People's Republic of Bangladesh: Article 17 (Free and compulsory education)". bdlaws.minlaw.gov.bd. Retrieved 2 May 2017.

"Primary education now up to class VIII". The Daily Star. 18 May 2016. Retrieved 12 September 2016.

"Private University - Banglapedia". en.banglapedia.org. Retrieved 16 September2016.

"University Grants Commission - Banglapedia". en.banglapedia.org. Retrieved 16 September 2016.

"O level - GCE - Exams - British Council - Bangladesh". British Council. Archived from the original on 2 February 2008. Retrieved 12 September 2016.

Ahmad, Mumtaz (2007). "Islam, state, and society in Bangladesh". In Esposito, John; Voll, John; Bakar, Osman. Asian Islam in the 21st Century. Oxford: Oxford University Press. p. 56. ISBN 978-0-19-804421-5.

Tan, Charlene, ed. (2014). Reforms in Islamic Education: International Perspectives. New York: Bloomsbury Academic. p. 91. ISBN 9781441101341.

Alam, Mahmadul; A.T.M Shaifullah Mehedi; Nehraz Mahmud (2013). "Religious education in Bangladesh". In Davis, Derek; Miroshnikova, Elena. The Routledge International Handbook of Religious Education. New York: Routledge. pp. 48-49. ISBN 978-1-136-25641-7.

Ahmad, Mumtaz (2004)."Madrassa Education in Pakistan and Bangladesh". In Limaye, Satu P.; Wirsing, Robert C.; Malik, Mohan (eds). Religious radicalism and security in South Asia. Honolulu: Asia-Pacific Center for Security Studies. page 107.

Education Spending, Bangladesh, at theglobaleconomy.com Accessed 26 April 2017

Sedere, Upali M. (2000). "Institutional Capacity Building Through Human Resource Development". Directorate of Primary Education/PEDPQI Project of NORAD, Bangladesh.

"Roll Call: Teacher Absence in Bangladesh" (PDF). Site resources.world bank.org. 2004. Retrieved 25 October 2013.

Molla Huq: Gender Disparities in Secondary Education in Bangladesh, May 2008, at files.eric.ed.gov Accessed 26 April 2017

Abu S. SHONCHOY* and Mehnaz RABBANI: The Bangladesh Gender Gap in Education: Biased Intra-household Educational Expenditures, at ide.go.jp Accessed 26 April 2017

Niels-Hugo Blunch, Maitreyi Bordia Das: Changing norms about gender inequality in education: Evidence from Bangladesh Accessed 1 May 2017

"Country Profiles: Bangladesh". UNESCO Institute for Statistics. Retrieved 12 September 2016.

The Impact of Islamic Schools in Bangladeshi Society: The Case of Madrassa, March 27, 2014, at alochonaa.com Accessed 26 April 2017

"Bangladesh's literacy rate rises to 70 percent, education minister says". bdnews24. 16 June 2015.

Education system Bangladesh | EP-Nuffic | 1st edition October 2012 | version 1, January 2012

Bangladesh Education Commission Report. (1974). pp. 23 Ministry of Education. (2014). Bangladesh National Education Policy 2010, pp. 5, 19

www.educationboardresults.gov.bd

www.bteb.gov.bd/result_arch/

https://en.wikipedia.org/wiki/Education_in_Bangladesh 